UCRL-ID-129849

\title{
Materials To Be Used For Radionuclide Transport Experiments
}

\author{
B. E. Viani
}

Febuary 3, 1998

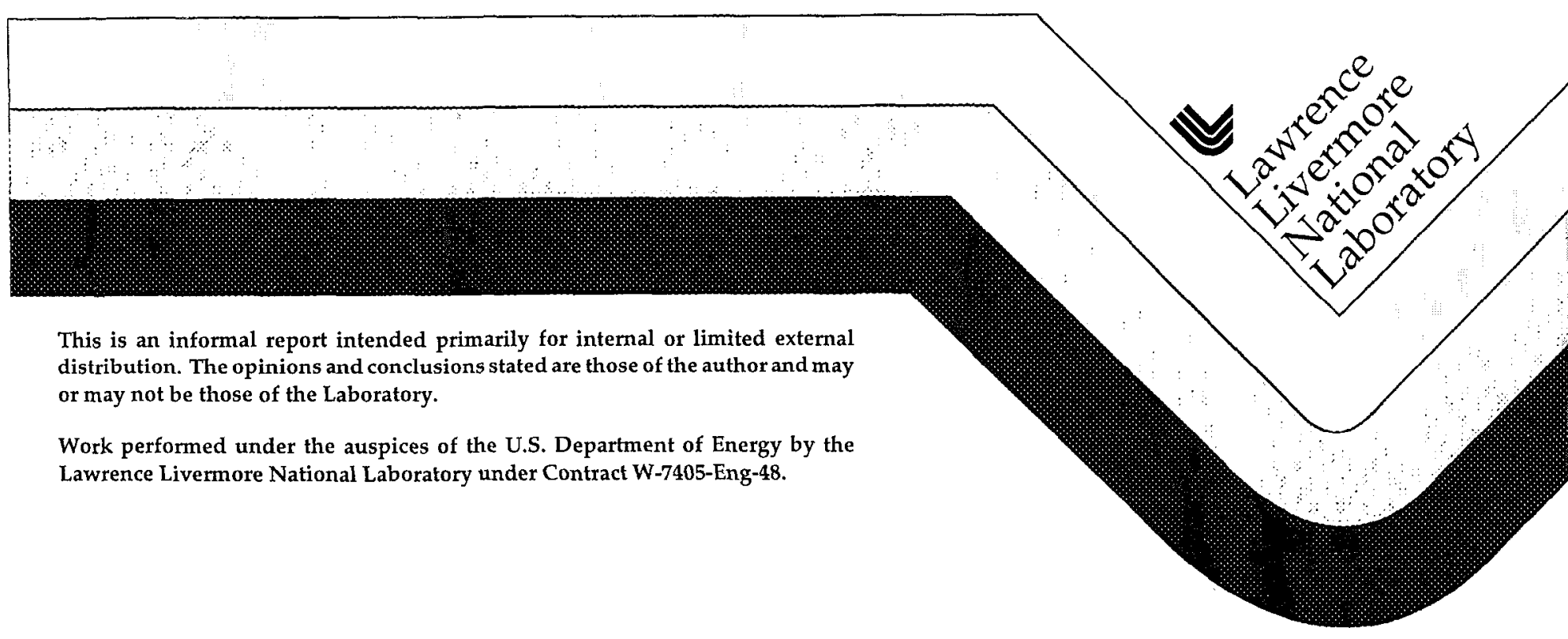




\section{DISCLAIMER}

This document was prepared as an account of work sponsored by an agency of the United States Government. Neither the United States Government nor the University of California nor any of their employees, makes any warranty, express or implied, or assumes any legal liability or responsibility for the accuracy, completeness, or usefulness of any information, apparatus, product, or process disclosed, or represents that its use would not infringe privately owned rights. Reference herein to any specific commercial product, process, or service by trade name, trademark, manufacturer, or otherwise, does not necessarily constitute or imply its endorsement, recommendation, or favoring by the United States Government or the University of California. The views and opinions of authors expressed herein do not necessarily state or reflect those of the United States Government or the University of California, and shall not be used for advertising or product endorsement purposes.

This report has been reproduced directly from the best available copy.

Available to DOE and DOE contractors from the Office of Scientific and Technical Information

P.O. Box 62, Oak Ridge, TN 37831

Prices available from (615) 576-8401, FTS 626-8401

Available to the public from the

National Technical Information Service

U.S. Department of Commerce

5285 Port Royal Rd.,

Springfield, VA 22161 


\title{
Letter Report \\ Materials To Be Used For Radionuclide Transport Experiments
}

Milestone SPL3A1M4

\author{
B. E. Viani
}

LLNL

\section{Summary}

Experiments to determine the effect of canister corrosion products on the transport of radionuclides will be undertaken using the Fe(III) oxides goethite and hematite as proxies for the expected corrosion envelope that will form as a result of alteration of the corrosion allowance overpack prior to the breaching of the waste container. Samples of ESF invert concrete that have been crushed, or left intact but fractured, and that have been subjected to hydrothermal alteration will be used to determine the effect of cementitious materials on transport of radionuclides. A mixture of $\mathrm{CaCO}_{3}, \mathrm{SiO}_{2}$, and aggregate will be used as a proxy for completely carbonated concrete.

\section{Introduction}

The release of radionuclides from breached waste canisters to the far field will require their transport through the engineered barrier system/near field environment (EBS/NFE). To derive a source term for repository performance assessment calculations, transport of radionuclides through two volumetrically and chemically significant materials that are expected to comprise the transport path must be assessed. These materials, corrosion products derived from the corrosion allowance overpack of the waste canisters, and the cementitious materials (concrete, grout, etc.) used in the repository construction, are expected to influence radionuclide transport because they interact strongly (retard, immobilize, generate radionuclide-bearing colloids, etc.) with important radionuclides, such as $\mathrm{U}$ and $\mathrm{Np}$ (Viani, 1995, 1996). Experiments to determine transport properties of $\mathrm{Np}$ and $\mathrm{U}$ in potential corrosion products and cementitious materials are planned for this fiscal year. The materials that will be utilized for these experiments are described below.

\section{Corrosion products}

The most abundant corrosion products resulting from degradation of the waste container are expected to be iron oxides derived from a relatively thick corrosion allowance overpack of low-carbon steel that is expected to surround a corrosion resistant inner barrier (Van Luik et al. 1992; Ahn and Soo, 1995). This steel is expected to undergo generalized corrosion as a result of interaction with hot humid atmosphere and contact by liquid groundwater during the post dry-out period of the repository. The end result of the corrosion process is expected to be the development of a porous accumulation of oxides of iron surrounding the waste form and 
inner barrier. This porous medium has a high probability of being in the flow path of radionuclide-bearing fluids that leave the waste canister via breaches in the corrosion resistant inner barrier.

Compared to the repository horizon and adjacent rock units at Yucca Mountain, sorption partition coefficients on iron oxides are several orders of magnitude or more larger for elements such as $\mathrm{U}, \mathrm{Np}$, and $\mathrm{C}$ (Viani, 1996). Hence, corrosion products will be an important barrier to radionuclide transport through the EBS/NFE. However, because the products of corrosion are likely to be finely divided and porous, a potential for the introduction of colloids to the waste stream also exists.

The waste container and steel overpack is expected to be subjected to three distinct hydrothermal regimes during the repository lifetime. It is assumed that oxic conditions will prevail for life of the waste canister, and that oxygen will not be limited. Following waste emplacement, the waste package will be subjected to elevated temperatures and humidities in the absence of liquid water during the period in which water is driven away from the repository drifts. This regime will be followed by a period of contact by hot and relatively dry atmosphere during the dry-out stage of the repository. After temperatures in the drift drop below boiling, hot humid conditions will return. Finally, rehydration of the repository horizon could result in liquid water contacting the container. Depending on redox state and moisture conditions, low-carbon steel will corrode more or less uniformly by altering to oxides of iron that can include, $\mathrm{FeO}$ (wüstite), $\mathrm{Fe}(\mathrm{OH})_{2}, \mathrm{Fe}_{3} \mathrm{O}_{4}$ (magnetite), $\gamma-\mathrm{Fe}_{2} \mathrm{O}_{3}$ (maghemite), $\alpha-\mathrm{Fe}_{2} \mathrm{O}_{3}$ (hematite), $\mathrm{Fe}(\mathrm{OH})_{3}$ (amorphous iron hydroxide), $\gamma$ - $\mathrm{FeOOH}$ (lepidocrocite), and $\alpha-\mathrm{FeOOH}$ (goethite) (Evans, 1960).

Hot dry atmosphere - Even though corrosion rates are much reduced at ambient temperatures in the absence of liquid water and for relative humidities lower than a critical level (Evans, 1960 p. 486; Fyfe, 1976), corrosion films do form on steels at elevated temperatures in the absence of $\mathrm{H}_{2} \mathrm{O}$ vapor. Under dry conditions in the presence of oxygen, carbon steel corrodes to form a film of anhydrous oxides dominated by $\alpha-\mathrm{Fe}_{2} \mathrm{O}_{3}$ and $\gamma-\mathrm{Fe}_{2} \mathrm{O}_{3}$ for relatively low temperatures $\left(<200^{\circ} \mathrm{C}\right)$, and dominated by $\mathrm{Fe}_{3} \mathrm{O}_{4}$ at higher temperatures (Evans, 1960; pp. 24-26). Thus, during the dry-out period of the repository, assuming the availability of oxygen, anhydrous Fe(III)-oxides would be expected to dominate the corrosion film formed on the overpack steel.

Hot humid atmosphere - During the period before, and immediately following the dry out, the canister will be in contact with warm to hot moist air. Based on observations of corrosion of steel in humid atmospheres at ambient temperatures, the corrosion products ;are expected to be dominated by $\mathrm{Fe}(\mathrm{OH})_{3}$, and $\alpha$ - and $\gamma$-FeOOH (Booker, 1976; Furet et al., 1990; Kucera and Mattsson, 1987). Acceleration of corrosion by water vapor at ambient temperatures is well known (Evans, 1960, p. 486; Fyfe, 1976) but the effect of water vapor on the types of corrosion products formed at relatively low elevated temperatures $\left(<200^{\circ} \mathrm{C}\right)$ is not well documented. 
Liquid groundwater contact - Assuming the availability of oxygen, low-carbon steel will likely corrode in the presence of groundwater to form products similar to those observed under humid unsaturated conditions (i.e., $\alpha$ - and $\left.\gamma-\mathrm{FeOOH}, \mathrm{Fe}(\mathrm{OH})_{3}\right)($ Booker, 1976).

Microbial induced corrosion - During periods of elevated humidity and/or groundwater contact, there is a potential for microbiological induced corrosion (Hughes, 1976). Although there is a potential for sulfides to form as a result of microbial corrosion even under aerobic conditions (Borenstein, 1994), the ultimate products of such corrosion will likely be dominated by the hydrated oxides of Fe(III) under long term oxidizing conditions (e.g., Badan et al., 1991).

Expected oxide phases - Of the initial corrosion products that form under hot dry or humid warm conditions, $\gamma-\mathrm{FeOOH}$ (goethite) and $\gamma-\mathrm{Fe}_{2} \mathrm{O}_{3}$ (hematite) are the most likely phases that will persist in the relatively low temperature, oxygenated, humid environment of the post-dry out repository. Based on the observed genesis and persistence of iron oxide phases in soils, other corrosion product phases such as $\gamma-\mathrm{Fe}_{2} \mathrm{O}_{3}, \mathrm{Fe}_{3} \mathrm{O}_{4}$, and $\gamma-\mathrm{FeOOH}$ are likely to be transitory (Schwertmann and Taylor, 1989). Although hydrated oxides of Fe(III) appear to be the most likely initial constituents of the corrosion layers formed on low-carbon steel in the presence of water, in the long term, transformation of these phases to anhydrous $\alpha-\mathrm{Fe}_{2} \mathrm{O}_{3}$ (hematite) may occur. The relative thermodynamic stability of goethite and hematite is not known with certainty, although tabulated data suggest hematite plus water to be slightly more stable than goethite (Johnson and Lundeen, 1994; Schwertmann and Taylor, 1989). Both goethite and hematite are widely distributed in soils, and each appears to persist as the most stable phase for specific ranges in earth surface conditions (Schwertmann and Taylor, 1989). Repository regimes which maintain lowered water activity and elevated temperatures would favor the transformation of goethite to hematite, although the kinetics of this transformation may be slow enough to allow goethite to persist (Schwertmann and Taylor, 1989).

Materials to be used for transport experiments - The adsorptive properties of goethite, hematite, and other Fe(III) oxides based on mass are strongly influenced by their specific surface area. Specific surface area is related to degree of crystallinity and particle size. However, based on normalized surface area, the adsorptive properties of these phases are very similar (Dzombak and Morel, 1990; Schwertmann and Taylor, 1989). Transport properties experiments will be conducted using pure goethite and hematite to simulate the corroded overpack material. Because of the similarity of the sorptive properties of these phases, a full suite of transport experiments will be conducted with only one of the phases. Selected experiments with the other phase will be run to verify the expected similarity of the results.

Synthesis and characterization - The phases used in the experiments will either be synthesized according to techniques described in Schwertmann and Cornell (1991) or purchased, if available as reagent grade powders. The materials will be characterized for chemical composition (dissolution followed by inductively coupled plasma spectroscopic analysis), crystallinity and purity (xray diffraction), particle size and shape (scanning clectron 
microscopy), specific surface area (BET gas adsorption analysis), and surface chemical properties (titrametry).

\section{Cementitious Materials}

Cementitious materials in the form of concrete flooring (invert) and supports in emplacement drifts, shotcrete coating or concrete lining for drift wall stabilization, and grout for rock bolt anchoring, are expected to be present in the repository in significant quantities (Meike, 1996). Concretes that underlie the waste emplacement canisters are the most likely cementitious material to interact with radionuclide waste-bearing fluids. Although the chemical and physical properties of as placed concrete can dramatically affect the transport of radionuclides (Atkins et al., 1988, Albinsson et al., 1993), it is expected that by the time radionuclides are released from the waste canister, cementitious materials will have been subjected to and altered by 100 's to 1000 's of years of hot dry and hot humid conditions. Because of the chemical and mineralogical complexity of cementitious materials, and the dearth of relevant thermodynamic and kinetic data, the chemical and mineralogical properties of concretes that have been subjected to the conditions expected in the repository cannot be predicted with any degree of certainty (Bruton et al., 1994; Meike et al., 1994). Hence, the transport properties of radionuclides expected in altered cementitious materials is known with even less certainty.

The chemical and mineralogical properties of as placed concretes are dramatically unlike the repository horizon and surrounding rocks at Yucca Mountain. Pore fluids in relatively young concretes are commonly quite alkaline, having $\mathrm{pH}$ 's $>11$, and ionic strengths that are significantly larger than Yucca Mountain groundwaters due to the relatively high concentration of alkalis (Atkinson et al., 1989; Glasser et al., 1985). Colloidal silica-rich particles are abundant in fluids derived from concrete (Ramsay et al., 1988) in contrast to the rather low concentration of colloids in Yucca Mountain groundwaters (Triay et al., 1993; Viani, 1996). The mineralogical makeup of concrete is a mixture of the minerals composing the aggregate or structural component of the concrete, and the dominantly calcium silicate hydrate phases composing the cement component of the concrete. It is the mineral and chemical properties of the cement component that most affects the pore-water chemistry, and is the component likely to undergo the most significant changes as a result of the hydrothermal regimes imposed by the potential repository.

Concretes and cement phases have been shown to strongly retard and/or immobilize certain actinides, and in some cases, alkali radionuclides (Albinsson et al., 1993; Ma et al., 1996). Therefore, concrete may serve as a significant barrier to the release of radionuclides to the far field. The extent to which this barrier remains viable will depend on the nature of the physical and chemical alteration that occurs during the repository thermal periods.

Alteration of concrete under hot dry conditions - In contrast to alteration of metals, little empirical or thermodynamic data is available that could be used to predict the mineralogical changes in cements that would occur as a result of long-term dry heat (Meike, 1996). Although loss of imbibed and adsorbed water would be expected, the extent of the 
dehydration of the hydrated calcium silicate gels that comprise the bulk of the cement phases is unknown. Similarly, the rate and extent to which these gels would recrystallize to more stable and less hydrated phases is also unknown. To make bounding prediction regarding the effects of dry heat on concrete, thermodynamic data and long-term thermal experiments are required. Depending on the extent of dehydration and recrystallization during the dry out period, rehydration to form more hydrated phases would be expected during the longer period during which the repository rehydrates. Thus, dehydration may not be irreversible.

Experiments to assess the effects of dry heat on the mineralogical properties of concretes are currently being initiated in the Man Made Materials activity.

Alteration of concrete under hot wet conditions - Hydrothermal alteration of cements and concretes has been studied more thoroughly than hot dry heating. However, predicting the ultimate phase assemblage expected at the time radionuclide-bearing fluids contact these materials is still not possible due to large gaps in thermodynamic and empirical data. Relativcly short-term ( $<1 \mathrm{yr}$ ) hydrothermal treatments of cements and concretes in the presence of liquid water and, in some experiments, tuff, have shown that the hydrated calcium silicate gels in fresh concrete partly transform to crystalline phases such as tobermorite, xonotlite, etc. (Bensted, 1989). Whether these same phases would form in the absence of liquid water during the unsaturated, humid, and hot conditions expected in the repository is not known. Experiments are presently being started in the Man Made Materials activity to address these issues. The hydrated calcium silicate phases that have been observed in hydrothermally altered concretes, such as tobermorite, may be metastable, and their persistence under the hot humid, but unsaturated, conditions of the repository is unknown.

Carbonation of concrete - In addition to the transformations of calcium silicate hydrate gels to more crystalline phases, interaction of $\mathrm{CO}_{2}$ with these alkaline materials can result in the formation of $\mathrm{CaCO}_{3}$ (Taylor, 1990; Kobayashi et al., 1994). The degree and extent to which the cementitious materials in the repository will alter to $\mathrm{CaCO}_{3}$ will depend on a number of factors including, the atmospheric concentration of $\mathrm{CO}_{2}$ and $\mathrm{H}_{2} \mathrm{O}$, the temperature, and the rate of diffusion of $\mathrm{CO}_{2}$ into the cement (Saetta et al., 1993). When the $\mathrm{CO}_{2}$ concentration is high and diffusion is not a limiting factor, the conversion of finely divided calcium silicate hydrate minerals such as tobermorite or xonotlite to $\mathrm{CaCO}_{3}$ and $\mathrm{SiO}_{2}$ in the presence of $\mathrm{CO}_{2}$ at ambient temperature can be rapid (Goto, 1995; Martin, 1995; Meike, 1996). Extensive carbonation of the concrete would dramatically change the pore fluid chemistry. In particular, the highly alkaline pore fluids observed in concretes would no longer be expected; pore fluid $\mathrm{pH}$ would decrease by more than $3 \mathrm{pH}$ units. This change in chemistry would significantly affect the sorptive and immobilization potential of the concrete with respect to radionuclides. Mineralogical effects of $\mathrm{CO}_{2}$ interaction with cements and cement minerals are to be addressed this fiscal year in the Man Made Materials activity.

Materials to be used in transport experiments - A single well defined mineralogical assemblage can not presently be identified to be used as a proxy for altered cementitious materials in transport studies appropriate to the potential Yucca Mountain repository. Therefore, samples of concrete from the invert used in the ESF that have been thermally treated will be used as the starting material for the bulk of the radionuclide transport 
experiments. Two physical representations will be used in transport experiments: crushed material will be used to represent potential rubbleized concrete; intact cores with fractures will be utilized to represent coherent but fractured concrete. Depcnding on results of carbonation experiments, concretes subjected to hydrothermal alteration in the presence of excess $\mathrm{CO}_{2}$ or a mixture of phases expected to result from complete carbonation of the concrete.

Thermal treatments - Two types thermal treatments will be used to condition the concrete: saturated hydrothermal treatment at $150-200{ }^{\circ} \mathrm{C}$ using synthetic groundwater with a composition similar to $\mathrm{J} 13$; dry thermal treatment at $150-200^{\circ} \mathrm{C}$. Thermal treatments will be maintained for $4-6$ months. Transport experiments will be conducted using both untreated concrete and hydrothermally treated concrete. If time permits, the dry thermally treated samples will be used as well. Neither of the thermal treatments address the carbonation alteration process. If results from the carbonation experiments conducted in the Man Made Materials activity indicate that these reactions are to be extensive and rapid enough to provide useable material for future transport experiments, hydrothermal treatments using elevated $\mathrm{CO}_{2}$ levels will be started in anticipation of transport experiments to be performed late this fiscal year, or next fiscal year. Alternatively, an assemblage of phases consisting of $\mathrm{CaCO}_{3}, \mathrm{SiO}_{2}$, and an appropriate proportion of aggregate could be used to provide an approximation of a completely carbonated concrete.

The bulk of the transport experiments will be conducted using the hydrothermally altered concrete. To obtain bounds and comparison data, a lesser number of experiments will be conducted using unaltered concrete, dry heated concrete, and $\mathrm{CaCO}_{3}-\mathrm{SiO}_{2}$-aggregate mixture.

Characterization of materials - The as-received concrete samples and the treated concrete samples will be analyzed by xray diffraction, scanning electron microscopy, and possibly mercury porosimetry prior to use in the transport experiments. 


\section{References}

Ahn, T.M., and Soo, P. 1995. Corrosion of low-carbon cast steel in concentrated synthetic groundwater at 8-150 ${ }^{\circ} \mathrm{C}$. Waste Management 15:471-476.

Albinsson, Y., Andersson, K., Borjesson, S., Allard, B. 1993. Diffusion of radionuclides in concrete/bentonite systems. Swedish Nuclear Fuel and Waste Management Co. Technical Report 93-29. Stockholm, Sweden.

Atkins, M., Beckley, A.N., and Glasser, F.P. 1988. Influence of cement on the near field environment and its specific interactions with uranium and iodine. Radiochimica Acta 44/45:255-261.

Atkinson, A., Everitt, N.M., and R.M. Guppy. 1989. Time dependence of $\mathrm{pH}$ in a cementitious repository. Mat. Res. Soc. Proc. Vol. 127:439-446.

Badan, B., Magrini, M., and Ramous, E. 1991. A study of the microbiological-corrosion products of steel and cast iron pipes in fresh water. J. Mater. Sci., 1991 26:1951-1954.

Bensted, J. 1989. Oil well cements - A general review. Chem. Ind. 20:100-105.

Booker, C.L.C. 1976. Nature of films, scales, and corrosion products on metals. Pp. 1:22-31. In Shreir, L.L. (ed.) Corrosion Volume 1. Metal/Environment Reactions. Newnes Butterworths, London.

- Borenstein, S. 1994. Microbial Influenced Corrosion Handbook. Industrial Press. New York.

Bruton, C.J., Phillips, B.L., Meike, A., Martin, S., and Viani, B.E. 1994. Cement minerals at elevated temperature: Thermodynamic and structural characteristics. Mat. Res. Soc. Proc. Vol. 133:327-334.

Dzombak, D.A., and Morel, F.M. 1990. Surface Complexation Modeling: Hydrous Ferric Oxide. Wiley, New York.

Evans, U.R. 1960. The Corrosion And Oxidation Of Metals. Edward Arnold, London.

Furet, N.R., Haces, C., Corvo, F., and Diaz, C. 1990. Corrosion rate determination using Fe57 Mossbauer spectra of corrosion products of steel. Hyperfine Interactions. 57:1833-1838.

Fyfe, D. 1976. The atmosphere. pp. 2:26-37. In Shreir, L.L. (ed.) Corrosion Volume 1. Metal/Environment Reactions. Newnes Butterworths, London.

Glasser, F.P., Angus, M.J., McCulloch, C.E., Macphee, D., and Rahman, A.A. 1985. The chemical environment in cements. Mater. Res. Soc. Symp. Proc. 44:849-858. 
Goto, S., Suenaga, K., Kado, T., and Fukuhara, M. 1995. Calcium silicate carbonation products. J. Amer. Ceram. Soc. 78:2867-2872.

Hughes, D.E. 1976. The microbiology of corrosion. Pp. 2:73-82. In Shreir, L.L. (ed.) Corrosion Volume 1. Metal/Environment Reactions. Newnes Butterworths, London.

Johnson, J., and Lundeen, S. 1994. GEMBOCHS Thermodynamic Datafiles For Use With the EQ3/6 Software Package. Yucca Mountain Project Milestone Report M0L72.

Kobayashi, K., Suzuki, K., and Uno, Y. 1994 Carbonation of concrete structures and decomposition of C-S-H. Cement and Concrete Research. 24:55-61.

Kucera, V., and Mattsson, E. 1987. Atmospheric corrosion. pp. 211-284. In. Mansfeld, F. (ed.) Corrosion Mechanisms. Marcel Dekker, New York, NY.

Ma, W.P., Brown, P.W., and Komarneni, S. 1996. Sequestration of cesium and strontium by tobermorite synthesized from fly ashes. J. Amer. Ceram. Soc.79:1707-1710.

Martin, S.I. 1995. Synthesis of $1.1 \mathrm{~nm}$ tobermorite: A cement phase expected under repository conditions. Proc. Sixth International Meeting High Level Radioactive Waste Management, Las Vegas, NV, pp. 571-573, American Nuclear Soc., La Grange Park, IL.

Meike, A. 1996. Chapter 6: Introduced (Man-Made) Materials. In Wilder, D.E. (ed.) Volume II: Near-Field and Altered-Zone Environment Report. LLNL Report UCRL-LR-124998. Lawrence Livermore National Laboratory, Livermore, CA 94550.

Meike, A., Onofrei, M., Bruton, C.J., and Viani, B.E. 1994. Progress in understanding the structure and thermodynamics of calcium silicate hydrates. Proc. Fifth International Meeting High Level Radioactive Waste Management, Las Vegas, NV, pp. 32590-2596, Amcrican Nuclear Soc., La Grange Park, IL.

Ramsay, J.D.F., Avery, R.G., and Russell, P.J. 1988. Physical characteristics and sorption behaviour of colloids generated from cementitious systems. Radiochimica Acta 44/45:119124.

Saetta, A.V., Schrefler, B.A., Vitaliani, R.V. 1993. The carbonation of concrete and the mechanism of moisture, heat and carbon dioxide flow through porous materials. Cement and Concrete Research. 23:761-772.

Schwertmann, U., and Cornell, R.M. 1991. Iron Oxides in the Laboratory: Preparation and Characterization. VCH, New York.

Schwertmann, U., and Taylor, R.M. 1989. Iron oxides. pp. 379-438. In Dixon, J.B., and Weed, S.B. (eds.) Minerals in Soil Environments, Second Edition. Soil Science Society of America, Madison, WI. 
Taylor, H.F.W. 1990. Cement Chemistry. Academic Press. London.

Triay, I., Simmons, A., Levy, S., Nelson, S., Nuttall, H., Robinson, B., Steinkampf, W., and Viani, B. 1993. Colloid-facilitated radionuclide transport at Yucca Mountain. Los Alamos Report LA-12779-MS. Los Alamos, NM.

Van Luik, A., Stahl, D., and Harrison, D. 1992. Progress in waste package and engineered barrier system performance assessment and design. Mater. Res. Soc. Symp. Proc. 294:663$\mathrm{Xx}$.

Viani, B.E. 1995. Scientific Investigation Plan for YMP WBS Element 1.2.3.10.3.1 Integrated Radionuclide Release: Tests and Model Development (Integrated Testing). SIP-IT-01. Rev. 0 . Lawrence Livermore National Laboratory, Livermore, CA.

Viani, B.E. 1996. Chapter 7: Integrated testing. In Wilder, D.E. (ed.) Volume II: Near-Field and Altered-Zone Environment Report. LLNL Report UCRL-LR-124998. Lawrence Livermore National Laboratory, Livermore, CA 94550. 


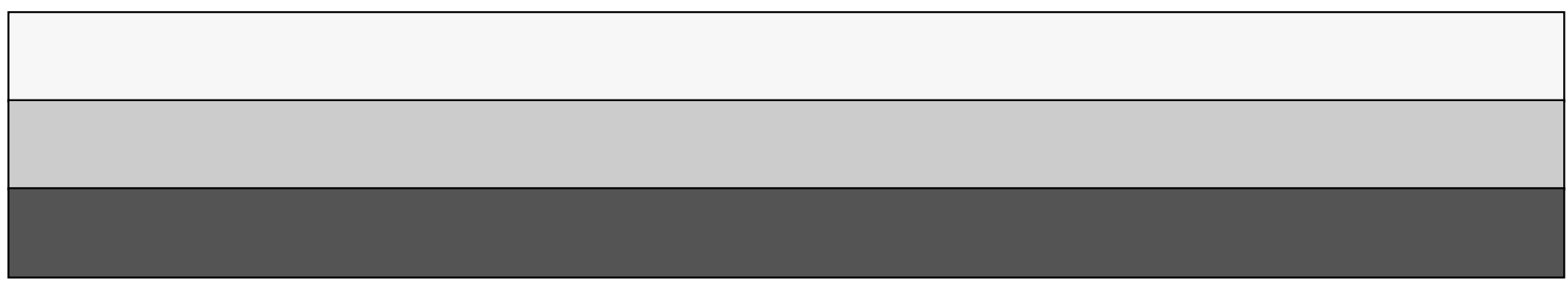

